\title{
IPOs and the Slow Death of Section 5
}

Donald C. Langevoort

Georgetown University Law Center, langevdc@law.georgetown.edu

Robert B. Thompson

Georgetown University Law Center, thompson@law.georgetown.edu

This paper can be downloaded free of charge from:

https://scholarship.law.georgetown.edu/facpub/1271

http://ssrn.com/abstract=2316858

This open-access article is brought to you by the Georgetown Law Library. Posted with permission of the author. Follow this and additional works at: https://scholarship.law.georgetown.edu/facpub

Part of the Business Law, Public Responsibility, and Ethics Commons, Finance and Financial Management Commons, and the Securities Law Commons 


\title{
IPOs and the Slow Death of Section 5
}

\author{
Donald C. Langevoort ${ }^{*}$ and Robert B. Thompson ${ }^{+}$
}

Section 5 of the Securities Act of 1933 is slowly dying. We have to be careful about making such a bold-sounding claim because Section 5 performs two distinct legal functions. First, it creates a presumption that offerings of securities using the facilities of interstate commerce have to be registered with the Securities and Exchange Commission ("SEC"). Elsewhere, we and others have described the momentous shifts in the pattern of exemptions that allow issuers to avoid registration, especially after the JOBS Act of 2012. ${ }^{1}$ This function is very much alive, albeit in ways that to us seem to push in the direction of more unregistered capital raising transactions rather than more public offerings.

That is not the aspect of Section 5 that concerns us here, however. A separate function takes up almost all of Section 5's statutory text: restraining the marketing of registered public offerings so that salesmanship does not run ahead of the mandatory disclosure that is supposed to inform investor decisions of whether to buy or not, something often referred to as "gun-jumping.", 2 This is a devolution we find interesting and insufficiently

\footnotetext{
* Thomas Aquinas Reynolds Professor of Law, Georgetown University Law Center.

${ }^{+}$Peter P. Weidenbruch Jr Professor of Business Law, Georgetown University Law Center.

${ }^{1}$ See Robert B. Thompson \& Donald C. Langevoort, Redrawing the Public-Private Boundaries in Entrepreneurial Capital Raising, 98 Cornell L. Rev. (forthcoming, 2013). See also Michael Guttentag, Protection from What?: Investor Protection and the JOBS Act, 13 U.C. Davis Bus. L.J. 207 (2013); William K. Sjostrom, Rebalancing Private Placement Regulation, 36 U. Seattle L. Rev. 1143 (2013).

${ }^{2}$ See James D. Cox et Al., Securities Regulation: CASes and Materials $154-55$ ( $7^{\text {th }}$ ed. 2013). "Beating the gun" was the phrase more often used to describe similar behavior before 1933 and in the first decades after the passage of federal securities laws. See Louis Loss, Securities Regulation (2d ed. 1961) at 194 et seq. Paul Mahoney describes pre1933 practice by selling agents to avoid similar bans by the underwriting syndicates of the day. See Paul G. Mahoney, The Political Economy of the Securities Act of 1933, 30 J. L. Studies. 1 (2001).
} 
examined in legal scholarship. Our focus will be entirely on the initial public offering ("IPO”), the paradigmatic form of issuer capital-raising, and not offerings by seasoned issuers. ${ }^{3}$

We describe this as a slow death because it began almost as soon as the Act was passed. As we shall see in Part I, Section 5 started as a simple, rigid and coherent rule that limited sales efforts to after the SEC had declared the registration statement "effective." The industry found this impracticable and to some extent just ignored it, setting in motion two decades of negotiations as to a proper balance between the demand for preeffective marketing and the concerns about gun-jumping. A legislative compromise, eventually reached in 1954, gave us the statutory language that is mostly still with us today. The 1954 amendments created the three distinct time periods in a registered public offering that beginning securities law students still struggle to master: the pre-filing period during which offers and sales were forbidden; ${ }^{4}$ the waiting period during which oral (but not written) offers were allowed; ${ }^{5}$ and the post-effective period, where sales occur and final prospectuses are delivered. ${ }^{6}$

For many decades, however, this compromise had considerable bite. It generated what we call the quiet period, during which issuers and underwriters had to limit severely what they said outside of the statutory prospectus (and how and when they might say it) if the communication might in any way "whet the appetite" of investors and thus be an illegal offer. ${ }^{7}$ Gradually, quiet period practices emerged that put pressure on Section 5's awkward distinctions, especially as between oral and written communications. In response to these and other concerns in a time of rapid

3 Seasoned equity offerings pose a different set of questions because the issuer raising capital is already publicly traded, and thus familiar to the marketplace. See CoX ET AL. supra note 2id. at 178-89. The evolution of the public offering for larger seasoned issuers is mainly about "shelf registration." Id. at 189-97. The demise of Section 5 in this context is even greater, but implicates an entirely different set of issues. Increasingly, seasoned issuer offerings are quite different in execution from IPOs. See Todd Hamblet \& Nora Gibson, Confidentially Marketed Public Offerings: Let's Get Technical, 45 Sec. Reg. \& L. Rep. (BNA) 1303 (July 15, 2013).

${ }^{4}$ COX ET AL., supra note 2, at 155-64.

${ }^{5}$ Id. at $164-74$.

${ }^{6}$ Id. at 174-78.

7 See Eric Chiapenelli, Gun-Jumping: The Problem of Extraneous Offerings of Securities, 50 U. Pitt. L. Rev. 457 (1989). 
technological evolution, ${ }^{8}$ the SEC acted in 2005 to thoroughly restructure the public offering environment through an extensive set of rule-based exemptions and safe harbors (the "2005 Reforms"). ${ }^{9}$ Section 5 lost much of its heft as a result. ${ }^{10}$ In subtle and striking ways that have thus far received mostly superficial analysis, the JOBS Act recently took away even more with respect to most IPOs. ${ }^{11}$

Our aim here is to document all this, and assess the current state of Section 5's fragile health. To document and assess is not necessarily to criticize. The compromise reflected in Section 5 was conceptually incoherent from the beginning, and tied to an understanding of the public offering process that quickly became outdated. Perhaps the quiet period was not that good an idea in the first place, or the markets have changed enough to demand a new regulatory regime. ${ }^{12}$ In Part II, we turn to a brief survey of the contemporary literature in financial economics on IPOs. Legal scholars have paid attention to certain aspects of the economics of public offerings, particularly the persistent underpricing that occurs and the abuses that ensue in allocating scarce shares. ${ }^{13}$ But by and large, the prevailing view of Section 5 among lawyers still seems rooted in an overly

8 Lurking in the background of these reforms are the First Amendment implications of Section 5, which operates as a form of prior restraint and might seem vulnerable to attack. See Joseph Grundfest, Regulation FD in the Age of Facebook and Twitter: Should the SEC Sue Netflix?, (Jan. 2013), http://papers.ssrn.com/sol3/papers.cfm?abstract id=2209525.

9 Securities Offering Reform, Rel. No. 33-8591, 70 Fed. Reg. 44722 (Aug. 3, 2005) (hereinafter "2005 Release”).

10 For a highly critical exploration, see Joseph Morrissey, Rhetoric and Reality: Investor Protection and the Securities Regulation Reform of 2005, 56 Cath. U. L. Rev. 561 (2007).

11 The JOBS changes on which we focus are in the form of revised procedures easing the regulatory obligations for public offerings by "emerging growth companies." The JOBS Act does much more than this, and these other reforms have received more careful attention. For our analyses, see Donald C. Langevoort \& Robert B. Thompson, "Publicness" in Contemporary Securities Regulation After the JOBS Act, 101 Geo. L.J. 337 (2013); Thompson \& Langevoort, supra, note 1.

12 See James D. Cox, Premises for Reforming the Regulation of Securities Offerings, 63 Law \& Contemp. Probs., 11 (2000).

13 E.g., Christine Hurt, Moral Hazard and the Initial Public Offering, 26 Cardozo L. Rev. 711 (2005); Sean Griffith, A Legal and Economic Analysis of the Preferential Allocation of Shares in Initial Public Offerings, 69 Brook. L. Rev. 583 (2004); Therese H. Maynard, Spinning in a Hot IPO: Breach of Fiduciary Duty or Business as Usual?, 43 Wm. \& Mary L. Rev. 2023 (2002). The perceived abuses coming out of all this because the subject of SEC and FINRA rulemaking, see COX ET AL., supra, note 2 at 135-36, as well as extensive class action litigation. 
simplistic and archaic impression of the offering process. The persistence of book-building as the standard mechanism for U.S. (and to a large extent global) public offerings, and the value embedded in it of facilitating the flow of information from the purchasers to the underwriter and visa versa, reveals a complex negotiation between underwriters and institutional buyers that helps explain much of what is happening prior to the effective date of the registration statement, from which we can learn a great deal.

Our principal claim in Part II is that the demise of Section 5's communication rules is best understood as an embrace of book-building, facilitating the two-way communication process on which that practice depends. But we also consider what might have been lost in this remarkable transformation of the selling rules. Because book-building involves communications with presumably sophisticated institutional investors, it becomes easy to doubt that there is much if any need for protection at all. But the finance literature also stresses the complex interplay between these institutional negotiations and the stimulation of largely retail investor-driven demand in the secondary trading market, which was once clearly within Section 5's constraint but is less so after deregulation.

To assess whether investors are better off or not as a result, we turn to two main justifications that have been given for the deregulation. The first is that any loss in prophylactic protection can be made up for by the threat of liability, particularly with an enhanced Section 12(a)(2). We find this unpersuasive for a variety of reasons. The other-amply visible in the long history of Section 5-is a faith in the "filtration" process, that retail investors gain protection because of the availability of the preliminary prospectus during the waiting period to those involved in the selling process if not the investors themselves. Here again we are not particularly convinced, as we explain in Part III. Putting aside the biased incentives that affect filtration, much of what is most important-and conveyed privately to the institutions in the course of book-building -is forward-looking information that probably need not appear in the formal disclosure, whether preliminary or final. None of this is an argument for returning to the old prophylactics of Section 5. But it is cause for the SEC and FINRA to pay closer attention to the retail investor effects of the IPO sales process, especially in the post-JOBS Act era. 
Before we begin, some basics are in order for those not especially familiar with public offerings. ${ }^{14}$ An issuer seeking to raise capital in a public offering must first prepare and file a detailed disclosure document with the SEC, called the registration statement, and then await the staff's approval before actually selling the securities. When satisfied that disclosure is adequate and selling can begin, the staff declares the registration statement "effective." The document that conveys the required information to investors (taken directly from the registration statement) is the statutory prospectus, which has both a preliminary and final form.

IPOs in the United States are generally done on a fixed-price basis. Roughly at the same time of the effective date, the issuer sells the entire amount of newly-issued securities at a discount to a syndicate of underwriters, who-directly or through other dealers-then quickly turn around and resell to investors at the price set forth in the registration statement, a process referred to as a firm-commitment underwriting. The investors who purchase directly from the syndicate will ordinarily be a mix of institutional investors (mutual funds, pension funds, etc.) and "retail" investors (households and individuals of varying degrees of sophistication), but usually more the former than the latter. Contemporaneous with the public offering the issuer will typically list its securities on a securities exchange, so that secondary trading of the newly issued securities begins immediately. Investors who were not allocated shares by the underwriters in the initial round can thus acquire shares on the open market, albeit at the market price prevailing at the time of their purchase rather than at the fixed price. Their sellers will be investors who received initial allocations and quickly "flip" those shares, or the underwriters. For a period of time after the start of trading, the underwriters will take steps to assure that the market price of the securities stays at or-preferably-above the fixed offering price.

Book-building is the effort that occurs prior to the effective date, mainly during the waiting period, as the underwriters negotiate over offering terms with sophisticated institutional investors who are key potential investors. What they learn in these negotiations helps them set the offering price, the economics of which we will consider in Part II. There

14 For further elaboration on this brief overview, see generally COX ET AL., supra, note 2, chap. 4; see also Charles Johnson, JR. \& JOSEPH McLAughlin, Corporate FinanCE AND THE SECURITIES LAWS (4 ${ }^{\text {th }}$ ed. 2012). 
we will see that the offering price will deliberately be set below what the market is likely to demand when secondary trading begins after the effective date.

\section{SECTION 5's Restraints On MARKETING: A DEVOLUTION IN FOUR ACTS}

The Securities Act of 1933 radically changed the legal structure governing how securities are sold in this country, first requiring that the full story about the company and its securities be told through the medium of a registration statement (and its statutory prospectus), and second blocking alternative channels of communication that might distort or preempt the statutorily required story. The first eighty years in some ways can be seen as a long retreat from the stark language of the statute's prohibition against communication, a story that divides into four distinct regulatory eras.

While the deregulatory direction is unmistakable, we see themes that show a more nuanced approach through all four eras attuned to broader themes of how information gets to investors and the price discovery that goes on in a pre-selling of IPOs where communication between market makers and potential buyers can be seen as aiding investor protection. That doesn't mean that the balance is not difficult and that the government can yield to political and industry pressure as to deregulatory changes, but it does require a more detailed analysis.

A. The Ban on Communications (and Selling) Before the Effective Date under the Original 1933 Template

President Franklin Roosevelt, in proposing securities legislation to the Congress in the first month of his administration, set out a goal "to put the burden of telling the whole truth on the seller."15 The President's message also highlighted concern about high pressure sales tactics that had produced "severe losses through practices neither ethical nor honest on the

${ }^{15}$ S. Rep. No. 47 at 6-7 \& H.R. No. 85 at $1-2,73^{\text {rd }}$ Cong. $1^{\text {st }}$ Sess. (1933). 
part of many persons and corporations selling securities." ${ }^{16}$ A prominent study of securities markets described as sales tactics designed "to induce customers to buy, rather than to inform them....[T]he guiding principles, and the devices were those that had been successfully employed in the fields of advertising and salesmanship."17 The heart of the "33 Act was section 5(a) with two broad prohibitions. First, no security could be sold unless a registration statement was in effect with the extensive disclosure about a company and its securities required by the Act; ${ }^{18}$ second, sales effort by other means were banned until that filing had been reviewed by a federal agency and declared effective. ${ }^{19}$

In the first two decades under the ' 33 Act, industry practices quickly pushed beyond the seeming bright-line prohibition on selling before the effective date of a registration statement while early agency regulators focused on distinguishing those communications that were helpful to investors (those that were "prospectus like") and those that were worrisome (those that indicated hard core selling). From the beginning it was clear the new law did not ban all communications by the issuer or underwriters. Face to face communications or other exchanges that did not take place via a means of intrastate commerce were not covered. The Federal Trade Commission, charged with administering the new act during its first year, quickly declared (as suggested by the House Committee report) that issuers could distribute circulars "clearly and unmistakably marked [as] informative only, negativing without equivocation either impliedly or expressly an intent to solicit offers to buy or to make an offer to sell."20 This introduced a conceptual dilemma of distinguishing between communication and solicitation that Professor Louis Loss said was to

16 Id.

${ }^{17}$ TwentiEth Century Fund, The Securities MARKETS (1935) at 566-67.

${ }^{18} 15$ U.S.C. §77e(a) (prohibiting sale or delivery of security unless registration statement in effect). See $\S \S 7,10$ and Schedule A for the material required in a registration statement

1915 U.S.C. §77e(a) (1933) (prohibiting offer to sell or offer to buy unless registration statement in effect). This language was moved into a new section 5(c) in 1954 and made applicable only to the period before the filing of a registration statement. See notes infra. After the effective date, sales communications could occur by free writing so long as the final prospectus had already been sent or given to the person receiving the communication or accompanied the communication. See 15 U.S.C. 77b(a)(10) exempting free writing from the definition of "prospectus" after the effective date, removing these communications from Section 5(b)'s otherwise blanket ban on the use of any prospectus that didn't meet the requirements of section 10. See 15 U.S.C. $\S 77 e(b)$.

${ }^{20}$ Sec. Act. Rel. 70 (1933); see H. R. Rep. No. 85, $73^{\text {rd }}$ Cong. $1^{\text {st }}$ Sess $12-13$ (1933). 
"plague both the Commission and the industry for twenty-one years" (i.e. until the 1954 amendments). ${ }^{21}$

During this first era, the SEC (to whom the administration of the Act was transferred in 1934 after the SEC's formation) focused its efforts on adaptations of the section 10 prospectus that would be permissible prior to the effective date of the registration statement. General Counsel opinions issued in 1935 and 1936 supported industry use of what would become the "red herring" prospectus and blue card summaries of prospectuses. ${ }^{22}$ The first refers to the red legend added to the communication disaffirming any intent to offer to sell, and the second to 5" x 8" cards sold by Standard \& Poor's to underwriters and dealers and their circulation among customers summarizing the registration statement material. ${ }^{23}$

Clearly the SEC contemplated that the information in the registration statement would be circulated during the waiting period. ${ }^{24}$ James Landis, one of the principal drafters of the statute and the Commission's second chair, described the introduction of the "completely novel" concept of the waiting period in section 5 as providing the opportunity "for the financial world to acquaint itself with the basic data underlying the security issue and through the acquaintance to circulate among the buying public as well as independent dealers some intimation of

\footnotetext{
${ }^{21}$ LOUIS LOSS, SECURITIES REGULATION (2d ed 1961) at 187.

22 Securities Act Release 464 (1935); Securities Act Release 802 (1936).

${ }^{23}$ See Louis Loss \& Joel SEligman, SECuRities REgulation (3D ED.) at 396-398. Other related actions during this first period include: (i) the SEC's April 1945 statement of policy that it would not accelerate the effective date of a registration statement if an inaccurate red herring prospectus had been circulated and not corrected; (ii) the promulgation of Rule 131 in December 1946 that a red herring was not generally an offer; (iii) the promulgation of Rule 132 in October 1952 providing a brief identifying statement covering no more than 16 specified topic would not be considered an offer the SEC's attendant statement of its acceleration policy. See Securities Act Release 3453 (1952).

24 LOSS 2D ED., supra note 21 at 187. (“Although any form of pre-effective solicitation by use of the mails or interstate facilities was categorically forbidden, the whole theory of the waiting period was that the information contained in the registration statement would be disseminated so that the investing public would be able to make an intelligent determination whether to buy when the statement became effective”); Address of SEC Chair James J. Caffrey, September 27, 1946 at 3 ( in discussing red herring prospectus, noting "we have from the earliest days recognized that getting reliable information out to the public during the waiting period was part of the fundamental policy of the law.”).
} 
its quality." ${ }^{25}$ The contemplated "acquaintance” necessarily was of an indirect or filtration variety. The actual delivery of the prospectus to purchasers was (and remains today) only required by statute with the delivery of the stock certificate or the confirmation of sale, which, of course, would not occur until after the investor was legally bound to the contract. ${ }^{26}$

The process by which this transmission of information was to occur was not entirely clear. Loss described it as an apparent expectation that underwriters and dealers "would disseminate information without in any way puffing his wares," a seemingly naïve assumption negated by the fact that "salespersons are not educators, and the concept of a reluctant salesperson soon proved to be as chimerical as the dream of a nation without a thirst." ${ }^{27}$ Much of the SEC's efforts, both in this period and after 1954, seemed focused on creating incentives for issuers to distribute the material in final prospectus before the time for delivery specified in the statute. The statute, from its origin, has permitted free writing after the effective date once the investor has received the final prospectus ${ }^{28}$ and the SEC in the pre-1954 period pursued a number of efforts to condition sales efforts prior to the effective date on receipt of all or almost all of the information in what would be the final prospectus by permitting a red herring prospectus, identifying statements or other communications. ${ }^{29}$ In a legislative process cutoff by the advent of World War II, the SEC staff proposed legalizing the red herring selling effort based on a condition precedent of the investors' receipt of a statutory prospectus before committing to the sale. ${ }^{30}$ But the time the discussion resumed after the war, the SEC staff had let go of the condition precedent while accepting the legal recognition of the red herring. Even then, the SEC chair floated the possibility of conditioning acceleration of a registration statement on all prospective and actual selling group members receiving a red herring

\footnotetext{
${ }^{25}$ James M. Landis, The Legislative History of the Securities Act of 1933, 28 Geo. Wash. L. Rev. 29, 35 (1959-60).

${ }^{26} 15$ U.S.C. $\$ 77 \mathrm{e}(\mathrm{b})(2)$.

${ }^{27}$ LOSS 2D ED., supra, note 21 at 187.

${ }^{28} 15$ U.S.C. §2(a) (10) (excluding free writing from definition of prospectus after the effective date).

${ }^{29}$ See LOSS 2D ED., supra note 21, at 187-193.

${ }^{30}$ Id. at 199-200. Loss describes the industry's response: permit sales immediately upon the effective date subject to an investor's right to rescission in the day after the sale if the purchaser had not received the final prospectus before the sale.
} 
prospectus, a filtration-encouraging requirement that made its way into later rules. $^{31}$ Professor Loss, a participant in those SEC staff discussions as a senior staff attorney, concluded that recognizing the red-herring prospectus for the selling document it is was "a decided improvement in the investor's protection even without his being guaranteed a prospectus for a minimum period in advance of his commitment."32

Yet, testimony at hearings for the 1954 legislation was that the ordinary non-institutional investors "hardly ever" saw a red herring prospectus and for many an identifying statement either. ${ }^{33}$ The larger issue, that was already visible in this first period, was the ability of issuers to do the selling they needed without the final prospectus or the red herring/ identifying statement alternatives, something they could do by oral communications unregulated by the ' 33 Act. Loss pointed to the "inability or the unwillingness of the Commission to effectively enforce the prohibition against pre-effective oral solicitation" by means of interstate telephone calls as a difficulty with the "pre-54 statute. ${ }^{34}$ Prior to the passage of the ' 54 amendments he described the state of affairs as "so prevalent, [that] there is real danger that an important feature of the Securities Act" the ban on communications that is our focus, "will become another Prohibition law."35

Why then would the SEC be willing to agree to a legislative change in 1954 that accepted more selling (not just in red herrings but also oral communications) without getting actual delivery of the statutory prospectus before the investor made the purchase decision? It would be possible to see this as reflecting a change in the political climate. This was the first time since the passage of the Securities Act of 1933 that Republicans controlled both the White House and the Congress. Yet the core decision on this point had been made years before when Democrats still controlled the

\footnotetext{
${ }^{31}$ Caffrey supra note 24 at 6 . This later became part of Securities Act Release \#4968 (April 24, 1969). See also Loss 2D ED., supra note 21, at 200 "The theory was that the very imposition of the twenty-four hour requirement would act as a powerful incentive to dissemination of the statutory prospectus during the waiting period.”

${ }^{32}$ Id. at 254-55.

${ }^{33}$ Hearings before the Comm. on Interstate and Foreign Commerce on H.R. 7550 and S. 2846, $83^{\text {rd }}$ Cong., 2d Sess. (1954) at 149-50, 158.

${ }^{34}$ Loss 2D ED., supra note 21 at 194.

${ }^{35}$ Louis Loss, SECURITIES Regulation (1951) at 255 (hereinafter “Loss $1^{\text {st }}$ Ed.,”)
} 
Commission. ${ }^{36}$ When the Eisenhower administration did arrive, it focused more on budget restraint than seeking deregulatory changes in the securities laws. ${ }^{37}$ The Republican SEC chairman termed the '54 legislation "modest housekeeping" changes and couldn't recall "any serious discussion of substantive legislative initiatives during his chairmanship." ${ }^{38}$ Alternatively it could have been an adjustment in the SEC's attitude toward filtration. Loss suggested that the Commission and its staff in 1941 and 1947 may have put too much emphasis on the prospectus as the principal tool of the disclosure philosophy, pointing instead to "other statutory and administrative reforms which might make for a greater measure of precommitment disclosure indirectly." ${ }^{39}$ It seems more likely that what we see is some recognition of the tradeoff between investor protection and selling that carries into the later periods. It was not just a trust in filtration and markets to sufficiently transmit the information that had been given to the SEC, but recognition of the value of information going the other way from purchasers to underwriters.

In discussing underwriter's use of oral solicitation at a time that selling was banned by statute, Loss describes the practice as based on the underwriters' conviction (and adds "perhaps correctly so") that "it was essential to the fulfillment of their function, at least if it was to be done with reasonable safety, that they test the market before committing themselves." ${ }^{40}$ Here is the precursor to the book building argument that didn't make its way into the legal literature for decades into the future. Underwriters who were buying from the issuer and taking the risk of the

\footnotetext{
${ }^{36}$ LOSS $1^{\text {ST }}$ ED., supra note 35, at 251 ("After five years this difference [referring to the Commission's and the industry's views in the 1941 -2 period discussed above] no longer seemed so vital.”)

37 Joel Seligman, The Transformation of Wall Street (3d ed. 2003) at 267 (describing drop in the number of SEC staff.)

${ }^{38}$ Id. at $271-272$.

${ }^{39}$ LOSS 2D ED., supra note 21, at 203.

${ }^{40}$ Id. at 194. The "perhaps correctly so" was an addition to Loss's second edition, published in 1961. In the first edition in 1951, then SEC lawyer Loss quoted a SEC commissioner characterizing the underwriters' action as "probably not with their hearts in their mouth, but doubtless with their tongues in their cheeks." Loss $1^{\text {st }}$ Ed., supra note 35 at 161, quoting Address by Commissioner McConnaughey at Amos Tuck School of Business Administration, January 22, 1948.

See also, Nathan D. Lobell, Revision of the Securities Act, 48 Colum. L. Rev. 313, 332 (1948) (gun jumping "stemmed from desire by underwriters to limit period of their risk of less than full distribution”).
} 
uncertainty as to the price at which they could resale an issue for which there was no pre-existing market information wanted to communicate with buyers before they committed to a purchase price with the issuer. They did it orally with nothing more than indications of interest that were not legally binding, relying on reputation to make the process work for both sides. ${ }^{41}$

Paul Mahoney notes that none of the prohibitions on communications were necessary in order to achieve the simple goal of requiring full disclosure. He prefers a rent-seeking explanation as the source of the ban on communications, pointing to the origins of "beating the gun" concerns in the 1920s before there were any federal securities laws when syndicates sought to ban selling efforts prior to an agreed upon date: "While traditionally described as mere pieces of the technical apparatus of full disclosure, these provisions imposed important limitations on both retail and wholesale competitors...best understood as a means to eliminate several specific competitive techniques that low-status securities dealers were successfully using against high-status dealers in the late 20s and early 30s." 42 If such rent-seeking occurred, it was fairly quickly undercut by industry participants occupying undefined space beginning in the immediate aftermath of the passage of the '33 Act, asserting as legitimate communications practices seemingly banned by the '33 Act and aggressively negotiating with the Commission over two decades to shape the law contrary to the initial statute. The result reflected greater space for selling prior to the effective date that permitted price discovery, with more practical safeguards against high pressure sales codified into the 1954 amendments.

B. Oral Communications and Broadened "Prospectus-Like" Communications Sanctioned by the 1954 Amendments

With the 1954 legislative amendments, which remains the statutory language still applicable today, the categorical ban on communications receded entirely from the waiting period and only applies to the pre-filing

\footnotetext{
${ }^{41}$ Loss 2D ED., supra note 21 at 194.

${ }^{42}$ Mahoney, supra note 3.
} 
period. ${ }^{43}$ The waiting period was opened to oral communication and greater written communication was permitted through a preliminary prospectus, the summary prospectus, tombstone ads, and an identifying statement. ${ }^{44}$

In the aftermath of the amendments providing new freedom for selling activities prior to the effective date, the regulatory focus shifted to the perils of high pressure selling prior to the filing of the registration statement and the use of mass media to do it. Speeches by SEC commissioners discussed appropriate factors to govern efforts to root out communications that would frustrate the purpose of the securities laws. ${ }^{45}$ In late 1957 the Commission issued a release with 10 examples that found its way into law school casebooks for decades into the future. The release clearly described its motivation as an effort to overcome what "apparently is not generally understood ... that the publication of information and statements, and publicity efforts generally, made in advance of a proposed financing, although not couched in terms of an express offer, may in fact contribute to conditioning the public mind or arousing public interest in the issuer or in the securities of an issuer in a manner that raised serious question whether the publicity is not in fact part of a selling effort.”46

Then in the fall of 1958, the Commission brought its first gun jumping proceeding since the 1954 changes. ${ }^{47}$ An underwriter's publicizing Arvida Corporation's land developments plans that would be the basis of the issuer's public offering was criticized for only presenting the positive side of the development plans. The Commission's formal opinion which followed the settlement of an injunction case and dismissal of an

\footnotetext{
${ }^{43}$ Language from 5(a) was moved to (c). See Chiappinelli, supra note 7.

44 The original language banning offers to sell used categorical language ("by prospectus or otherwise") that would sweep in oral communications as well as written communications if occurring by means of interstate commerce. In 1954 that language was simply shifted to a new section (c) where it only applied to the pre-filing period. That left section, 5(b)(1) to regulate selling efforts during the waiting period and its language was not as broad, only applying to "prospectus" with no mention of "or otherwise." Since prospectus is limited in §2(a)(10) to only written, and not oral communications, oral offers, after 1954, find their way into the unregulated zone.

${ }^{45}$ See Speech of Commissioner Orrick in 1957 (discussing” thinly veiled attempts") and Chairman Gadsby in 1958 (companies don't have to close PR departments).

${ }^{46}$ Securities Act Release \#3844 (Oct. 8, 1957).

${ }^{47}$ There had been only three SEC actions regarding gun jumping prior to 1954 and only one that would fit post-1954 structure focused on conditioning the market in the prefiling period. See Loss 2D ED., supra note 21, at 197-97.
} 
administrative proceeding cited the direction in the Congressional Committee Report from the 1954 legislation for the SEC to be "ever vigilant to prevent evasion of the basic statutory approach of full

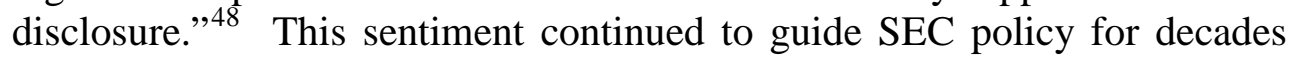
visible in the Google IPO in 2004 when the founders' interview published in Playboy magazine shortly before filing threatened to derail the company's IPO because of concern about a gun jumping communication. ${ }^{49}$

In the period after Arvida, the SEC's communications' shifted to making room for increasing information coming into the marketplace under disclosures required by the 1934 Act and to permit information directed toward customers, suppliers and employees. ${ }^{50}$ The Wheat Report in 1969 expressed the concern that gun jumping had unnecessarily interfered with normal publication activities of companies. ${ }^{51}$ Thereafter the Commission amended existing rules and added several new rules liberalizing communications. $^{52}$ The changes reflected the Commission's belief that "widespread market following greatly lessens the potential for abuse section 5 was intended to prevent." ${ }^{\text {" }} 3$ The specific context was the integrated disclosure system's impact on securities issuance by companies that were already within the disclosure requirements of the 1934 Act, but they also reflected acceptance of the impact of market disclosures and the greater role of institutional investors that could also impact issuances in an initial public offering, particularly as technology opened up more channels for information through the internet and other electronic communications.

During this period, the SEC continued its prior efforts to more broadly disseminate the required disclosure of the final prospectus. Its 1970 promulgation of Rule 15c2-8 comes as close as securities law has ever come to requiring that investors actually receive a copy of the full story in

\footnotetext{
${ }^{48}$ In re Carl M. Loeb Rhoads \& Co., 38 SEC 843 (1959).

${ }^{49}$ See Eric Schmidt, How I Did It: Google's CEO on the Enduring Lesson of a Quirky IPO, Harv. Bus. Rev. (May 2010) (the Playboy interview "almost derailed the whole process." available at http://hbr.org/2010/05/how-i-did-it-googles-ceo-on-the-enduring-lessons-of-aquirky-ipo/ar/pr). The solution, to add the interview as an appendix to the SEC filing fulfilled the full disclosure part of Section 5 without any apparent cooling off period that might address conditioning the market concerns.

${ }^{50}$ See e.g. Rule 169, 17 CFR §230.169.

${ }^{51}$ SEC, Disclosure to Investors: A Reappraisal of Administrative Policies under the '33 and '34 Securities Acts (1969) at 127.

${ }^{52}$ Securities Act Release 5180 (1971) (amending Rule 135 and adopting Rules 137-139).

${ }^{53}$ Release adopting Rule 139 and adding 139(b) (1984).
} 
the statutory prospectus prior to making the decision to buy,. ${ }^{54}$ This rule requires broker-dealers to deliver a copy of the preliminary prospectus to any person expected to receive a confirmation of sale at least 48 hours prior to anticipated mailing a confirmation. ${ }^{55}$ Yet this implementation of getting out the full disclosure which had been discussed by securities regulators for decades occurs in a somewhat convoluted way, not as part of a 1933 Act rule-making but as part of 1934 Act provisions regulating the deceptive acts of broker-dealers more generally.

Industry practices continued to develop that focused on communications outside of the regulated channels. Road shows permitted issuers and the selling group to both sell and get feedback from potential purchasers about their interest and the price they would be willing to pay. ${ }^{56}$ When advances in communications technology permitted road show presentations to be distributed to those that could not be physically present, the SEC deemed these communications not be a prospectus. ${ }^{57}$

The finance literature was quicker than the legal literature to connect these changes in communications policy to book building and the economic function of price discovery in the IPO process, with the underwriter acting as a reputational intermediary between issuers and investors as discussed in Part II. ${ }^{58}$ While there remains debate in the finance and legal community about the reach of these theories, the unwillingness of the SEC to implement a broad ban on communication reflects recognition of the value of price discovery.

Underpricing is a more visible illustration of this tension between communications and the process of price discovery in the IPO process. Although there were a couple of isolated references to underpricing in the

\footnotetext{
${ }^{54}$ Securities Act Release 5101 (1970).

55 Rule 15c2-8(b). Other parts of the rule also require brokers and dealers to take reasonable steps to furnish take reasonable steps to comply with written requests for the preliminary or final prospectus and to those expected to solicit customer orders.

${ }^{56}$ See Bro Utal, Inside the Deal That Made Bill Gates \$350,000,000, Fortune July 211986 23, 32 (describing six big investors threatening to 'uncircle"- to remove themselves from Goldman Sachs list two days before the deal became effective. "Chicago and Baltimore were fraying at the edges," but West coast investors stood firm and the IPO went public at the \$21 that Goldman had told investors was the target price.

${ }^{57}$ See e.g. Exploration, Inc. No Action Letter (October 9, 1986).

${ }^{58}$ See e.g. William Wilhelm, Bookbuilding, Auctions and the Future of the IPO Process, 17 J. App. Corp. Fin. 2 (2005).
} 
legal literature as far back as the 1940s, it was not until the mid 1980s that the topic seemed to reach a critical mass of attention in the legal literature. ${ }^{59}$ Some of the discussion of this era tracked the idea put forward earlier of the underwriter's risk in making a market that can be reduced by underpricing, with a sometimes recurring theme that underwriters were taking advantage of the process. ${ }^{60}$ Even so, the legal literature was a good ways behind the finance discussion of book building and underpricing's relation to the underwriter's price discovery process in discussions with buyers based on the underwriter's role as a reputational intermediary, to be discussed in Part II.

\section{The 2005 Reforms}

By the turn of the most recent century, many accommodations had been made to the practicalities of book-building, but the 1954 revisions were still amply visible in establishing the basic regulatory framework for IPOs. Gun-jumping liability remained a significant threat, at least as enforced (with considerable discretion) by the SEC staff. In 2005, however, there was something of a revolution.

The 2005 reforms were decades in the making, largely driven by the frustration of applying the stringent public offering rules to seasoned issuers when so much information is already available about them as a result of their public company status under the Securities Exchange Act. ${ }^{61}$ Fortunately we can ignore most of these reforms for our discussion, either because they do not apply to IPOs or, even if they do, because they do not involve Section 5's communication rules.

Two major changes, however, did significantly affect the IPO process - one for the pre-filing period, the other post-filing. New Rule 163A created a limited 30-day window prior to the filing of the registration

\footnotetext{
${ }^{59}$ See Barbara Banoff, Regulatory Subsidies, Efficient Market and Shelf Registration: An Analysis of Rule 415, 70 Va. L. Rev. 135 at footnote 82 (1984) (discussing underwriter incentives to underprice ; Ronald Gilson \& Reinier Kraakman, The Mechanisms of Market Efficiency, 70 Va. L. Rev. 549, at note 197 (1984).

${ }^{60}$ Banoff, supra note 59.

${ }^{61} 2005$ Release, supra note 9 at 44724.
} 
statement during which the quiet period attaches; offering communications by the issuer (not underwriters or dealers) before that time are excluded from the definition of offer, and hence from the prohibition in Section 5(c). ${ }^{62}$ In other words, the duration of the pre-filing period is shortened considerably, and issuers are free to "hype" up until the appointed time so long as their communications do not reference the forthcoming public offering and efforts are made to assure that the publicity is not repeated within the 30-day period. ${ }^{63}$

The SEC's explanation was that hyping that occurs more than thirty days out is unlikely to have an on-going conditioning effect on investors by the time they make their decisions to buy. ${ }^{64}$ While the Commission is no doubt right that publicity's effects do dissipate over time, we can at least wonder whether concerted efforts to create a buzz about a company and its prospects don't have lingering effects in terms of follow up word-of-mouth, journalistic coverage, etc. It may be naïve to think that publicity that whets the appetite of potential investors ceases to have that effect so quickly. Even though there is the prohibition on referencing the forthcoming offering, the issuer has the freedom to make such an announcement separately pursuant to long-standing Rule 135-the market for IPOs can then easily make the connection. ${ }^{65}$

The other major reform affecting IPO communications-one of the headline changes in the 2005 revisions - was the authorization for the issuer and offering participants to use "free writing prospectuses" ("FWP") after the filing of a registration statement containing a bona fide expected price range. ${ }^{66}$ FWPs are written marketing material of any sort-e-mails, term sheets, sales literature, media publicity. ${ }^{67}$ The relevant safe harbor rules (Rules 164 and 433) are mind-numbingly complicated but boil down to three possibilities, depending on who is responsible for the material and how or to whom it is communicated: (1) the inclusion of a legend warning readers that a prospectus is/will be available and should be read; (2) attachment of the most recent preliminary prospectus, which may be via

\footnotetext{
6217 CFR §230.163A.

6317 CFR §230.163A(a).

64 Id. at 44740.

6517 CFR §230.135.

6617 CFR §230.164.

6717 CFR §230.405.
} 
hyperlink for electronic materials; and (3) filing with the SEC. ${ }^{68}$ This is truly "free writing" in that there are no limitations on what can be said or how it can be communicated, so long as there is no inconsistency with what is in the registration statement.

This is a vast oversimplification of the FWP regime, ${ }^{69}$ but enough for our purposes. What is amply clear is the SEC had abandoned its 1954 philosophy that had tried to make the preliminary prospectus and similar documents the only written communications containing the kind of information that could make an investor want to purchase up until the effective date. The new philosophy was one of free communication (albeit with some combination of the three conditions) of whatever the offering participants want to say, so long as the best available prospectus is available to counter any overly optimistic implications from the FWPs.

The SEC was unapologetic about this profound change, making clear that the passage of time and evolution in information technology had made the old oral/written distinction both anachronistic and unwise. ${ }^{70}$ This reform unleashed opportunities for much more aggressive selling efforts during the waiting period. Acknowledging this, the Commission said that any excesses should be curbed not by prior restraint but by the threat of liability if what is said in the FWP is actually false or misleading. ${ }^{71}$ To this end, the 2005 reforms revised the liability rules under Section 12(a)(2) of the Securities Act, a provision that allows purchasers to recover against their sellers if sales are made, negligently, by means of a false or misleading "prospectus or oral communication."72 Notably, the reforms purported to

\footnotetext{
6817 CFR §230.433

69 For more, see COX ET AL. supra note 2, at 168-70.

702005 Release, supra note 9, at 44744.

71 See Securities Lawyer Predicts Success for Forthcoming SEC Offering Rule Proposals, 36 Sec. Reg. \& L. Rep. (BNA) 1894 (quoting Alan Beller, the Director of the Division of Corporation Finance, as saying that "so long as there are liability standards for material misstatements and material omissions in all written statements, the restrictions on written communications should not have to be as tight as they currently are.”)

7217 CFR §230.159A (defining “to offer to sell” to include an issuer offering or selling by means of a free writing prospectus prepared on behalf of the issuer or sued by the issuer).
} 
expand issuer liability, even when the issuer is a step or two removed from the plaintiff-purchaser. ${ }^{73}$ We will come back to all this in Part III.

We will turn soon to whether all this is good policy or not. For now, simply appreciate the extraordinary turn away from the statutory structure created in 1954. Until 2005, the IPO lawyer's job was often simply to say no to an issuer or underwriter that wanted to promote the forthcoming offering in a way that ran afoul of Sections 5(b) or 5(c) —-any selling efforts before filing, and written solicitations afterwards. Now, except in the brief thirty day window prior to filing, the desired selling efforts could occur, with the lawyer simply assessing whether the communication needed a legend or attachment, had to be filed, or was false or misleading. The edifice built in 1954-itself a compromise from what had been enacted in 1933 — had largely been torn down.

\section{The JOBS Act Relief for Emerging Growth Companies}

The 2005 reforms barely had time to become familiar before the financial collapse and global recession destabilized much of finance. As the U.S. struggled to regain its economic vigor, efforts to promote capital formation and hoped-for job creation became a priority for the nation's lawmakers. The JOBS Act of 2012 was a largely bipartisan response that specifically sought to encourage more IPOs by eliminating some of the regulatory burdens new public issuers face under both the '33 and '34 Acts-building a so-called "on-ramp" for issuers that qualify as emerging growth companies ("EGCs"). ${ }^{74}$

\footnotetext{
73 Rule 159A; see COX ET AL., supra note 2 at 538-39. The reforms also made "time of sale" the measure for assessing whether solicitation material was false or misleading, not any subsequent filings.

74 See Langevoort \& Thompson, supra, note 11. Section 101 added §2(a)(19) to the '33 Act, defining emerging growth companies as revenue with less than $\$ 1$ billion. The vast majority of IPO issuers fall into the EGC category. For a thorough set of data and commentary, see LATHAM \& WATKINS, THE JOBS ACT AFTER ONE YEAR: A REVIEW OF THE NEw IPO PLAYBOOK (April 5, 2013), available at http://www.lw.com/news/jobs-actat-one-release (hereinafter "Latham \& Watkins report”). See also ERNST \& YoUnG, THE JOBS ACT: ONE-YEAR ANNIVERSARY (April 2013).
} 
As with the 2005 reforms, we can ignore much of this deregulation. To be sure, there are aspects of the IPO deregulation that are controversial and deserve close attention, like the invitation for new issuers to make a confidential filing of their registration statement. But they do not involve Section 5's communication rules, and so are not our concern here.

There are two major changes that do. The first, in new Section 5(d), is the authorization for both issuers and offering participants to communicate in the pre-filing period with accredited institutional investors in order to "test the waters" before committing to a public offering. ${ }^{75}$ This goes well beyond the 2005 reforms because it enables conversations that focus specifically on the possible offering, and invites underwriters to take part. This is a moderate reform insofar as it limits contacts to those with presumably sophisticated institutions. It can be seen as a form of pre-bookbuilding, though no doubt the intention is to allow conversations with key investors as to whether the offering is worth doing in the first place.

The second is far more interesting, and requires a bit of background. Broker-dealer firms have long provided so-called sell-side research on publicly-traded companies, including recommendations to buy, sell, or hold. Were research to be initiated at the time of an IPO, it would presumably violate Section 5, as a written "offer" by an underwriter or dealer, whether or not the research was published by a deal participant. ${ }^{76}$

For offerings by seasoned issuers, the SEC has for some time had safe harbor rules that enable research to occur or continue even though a public offering is taking place. The most sensitive of these is Rule 139, which sets the conditions under which even underwriters - with an obvious self-interest in promoting the offering-can continue to publish research. ${ }^{77}$ But Rule 139 has never been available with respect to IPOs. ${ }^{78}$ Around the time the tech-stock bubble burst a little more than a decade ago, ample evidence arose that underwriters were using the promise of favorable research coverage as a means of obtaining investment banking business but harming purchasers. The resulting scandals led to a variety of restrictions designed to build a "wall" between research and banking. Research by deal

\footnotetext{
${ }^{75} 15$ USC §77e(d).

${ }^{76}$ As of 2005, such research publications could presumably be a free writing prospectus.

77 See COX ET AL., supra note 2, at 186-88.

${ }^{78} 17$ CFR §230.179(b) (applied to issuers required to file periodic reports under the 1934 Act).
} 
participants was impermissible until the offering was complete and (by FINRA rule) insider lock-ups had expired. ${ }^{79}$

Whether all this was something of an over-reaction is debatable. ${ }^{80}$ Positive research does make issuers more visible to investors, supporting a higher market valuation. The overall decline in the number of analysts covering smaller issuers, particularly after the introduction of decimalization reduced spreads in traded stocks, has sometimes been cited as a reason for the decline in IPOs. The IPO community took the JOBS Act as an opportunity to seek relief, and Congress delivered. Research analysts were given the freedom to take more of a role in discussions with potential issuers, and underwriters and other deal participants could initiate coverage at the time of the offering. ${ }^{81}$

This was controversial enough-obviously, the pressure on analysts will be to help sell the stock and support the after-market. But those conflicts are fully disclosed, and other regulatory restrictions remain in place, so that the precise effects to this new form of sales pressure are hard to estimate. ${ }^{82}$ We can almost certainly put this reform in the category of trading lower investor protection for enhanced capital formation, but it is not clear by how much. But the controversy over this amply visible deregulation almost completed obscured a much bigger impact on Section 5.

The proponents of enhanced sell-side research at the time of an offering wanted to promote oral as well as published research. For this the standard regulatory safe-harbor description of research then in use would not work - the SEC had, as recently as the 2005 reforms, refused to extend the safe-harbors to oral dissemination of recommendations. ${ }^{83}$ Instead, the JOBS Act alters the definition of both "offer" and "prospectus" (the key words in Section 5) to exclude a research report, with research report then

7917 CFR §230.139; Cox et al., supra note 2, at 135-36, 1039-41.

80 See Jill E. Fisch, Does Analyst Independence Sell Investors Short?, 55 UCLA L. Rev. 39 (2007). There has been significant evidence of a reduction in the research coverage of smaller issuers since the reforms went into effect.

8115 USC 77e(3) (publication by a broker or dealer of a research report about an emerging growth company is not a prospectus or offer).

82 Some finance scholars called into question whether recommendations by conflicted analysts distorted stock prices in the first place. See Agrawal \& Chen, Do Analyst Conflicts Matter: Evidence from Stock Recommendations, 51 J. L. \& Econ. 503 (2008).

832005 Release, at 44762. 
defined to mean any "written, electronic, or oral communication [by a broker or dealer] that includes information, opinions or recommendations with respect to the securities of an [EGC] . . . whether or not it provides information reasonably sufficient upon which to base an investment decision." 84

One can see how this might seem necessary to authorize the oral communication of sell-side research, and the phrase referring to "reasonably sufficient" simply takes from language drafted by the SEC in $2005 .^{85}$ But step back and ask whether there any form of salesmanship by an offering participant-even e-mail spam-that is not effectively eliminated from Section 5 when the issuer is an EGC. If read literally, this takes out of Section 5's communication rules the very sort of action that section is most concerned with: sales efforts to whet the appetite of investors, whether prefiling or during the waiting period. With respect to underwriters and dealers, it leaves Section 5(b) and (c) an empty shell.

All this was largely missed in the immediate aftermath of the JOBS Act. ${ }^{86}$ Once the SEC realized what had happened, it engaged in nonacquiescence, ${ }^{87}$ apparently believing that Congress' intent could not have been such a thorough gutting of the statute. We will have to see how all this eventually plays out, but in a world of textualist statutory interpretation, it is hard to see how Congress' words mean anything except what they literally say. To this point, the industry has been cautious in using the new freedom it was given as a result of the research rule reforms-other parts of the securities laws permit the SEC and FINRA to respond to overreaching here-but the potential breadth of the change is startling. ${ }^{88}$

\footnotetext{
${ }^{84}$ Section 2(a)(3) of the '33 Act.

852005 Release, supra note 9 at 44762. This contrasts with other forms of the regulation of analyst research, like Section 15D(d) of the '34 Act, 15 USC §77o-6 (d) and the SEC's Regulation A-C, 17 CFR $\$ 242.501$ et seq., which refer to reports that are sufficient on which to base an investment recommendation. While the more expansive permission granted by revised Rule 139 was not very well explained, it was clearly designed to free up less formal selling activity.

86 The issue is discussed in COX ET AL., supra note 2, at 160.

87 See Latham \& Watkins report, supra note 74 , , at 13.

88 Practitioners have good cause to be cautious and so we do not want to overclaim here. Among other things, many of the analyst research rules still apply, and this has been a high visibility enforcement area for the SEC. In addition, FINRA rule 2210 regulates customer
} 


\section{E. Summary}

Even if we put aside the JOBS Act research reforms, Section 5 is now a far different, less fearsome restraint on the IPO selling process than it once was. It reflect a faith that selling efforts are not so troubling as long as a preliminary or final prospectus is available to the potential investor and/or the investment professionals involved on both the sell and buy sides. We are thus left with the question of whether Section 5's slow death-and the more vigorous selling efforts that have evolved—should trouble us.

\section{Evaluating Section 5’s Demise}

\section{A. The Economics of IPOs}

IPOs can be promoted much more aggressively in light of the changes detailed in Part I. Determining whether this is problematic best begins by looking at the economics of the IPO process, one of the most thoroughly-studied subjects in finance.

Almost by definition, an IPO is about price formation in the absence of a fair interplay of supply and demand that sets an equilibrium market price. That is to say, up to the time of trading (and probably a while thereafter), there is no reliable objective measure of the value of the security, and in all likelihood substantial subjective disagreement. ${ }^{89}$ So a

communications that would apply to the kinds of communications seemingly excluded from "offer" and "prospectus." See id.

${ }^{89}$ There are trading markets for non-public issuers, but to this point it does not appear that they offer enough depth and liquidity to offer a reliable market price. See Langevoort \& Thompson, supra note 11; Elizabeth Pollman, Information Issues on Wall Street 2.0, $161 \mathrm{U}$. Pa. L. Rev. 179 (2012). All this might change in the future, in which case there might be opportunities to take advantage of private markets as IPO substitutes. See A.C. Pritchard, 
demand curve has to be created, and book-building-eliciting non-binding bids from sophisticated institutional investors as a result of the sequence of closed road shows and private communications-is the dominant solution to how to go about finding the optimal fixed offering price. ${ }^{90}$

One of the enduring puzzles in finance has to do with the predictable underpricing of IPOs as an artifact of book-building. Over the past decades, with a high degree of regularity, the short-term secondary market price rises after the effective date, often considerably - the so-called "pop" in the stock price. That suggests that the fixed offering price could have been higher, so that the issuer has left money on the table by not taking sufficient advantage of the demand for its securities. We have to be careful here, because the prevailing market price reflects the demand for single shares rather than the amount that it would take to find enough buyers to take the issuer's entire supply. But even so, the magnitude of the underpricing requires explanation.

The standard account is informational, which is often put forward to justify the entire enterprise of book-building. Institutional investors have private information - the product of their own proprietary research as well as their own demand preferences-that is costly to reveal. They will not be open and candid with the underwriters unless given a credible commitment that they will be compensated, and so book-building will fail. Underpriced allotments are the solution: the underwriters make an implicit promise that in this or subsequent offerings they will be paid for the value of the information embedded in their bids, based on how forthcoming and aggressive they are. Because underwriters and these large institutions deal with each other repeatedly, reputational incentives suffice.

Here the controversy begins. Accepting this basic premise, is the underpricing no more than necessary to induce the key investors' candor and participation? Although underwriters are formally limited to their 7\% spread in terms of their own compensation, they might be able to favor their repeat institutional customers by underpricing more aggressively and

Revisiting "Truth in Securities Revisited:" Abolishing IPOs and Harnessing Private Markets for Public Good, 36 Seattle U. L. Rev. 999 (2013).

${ }_{90}$ See Lawrence Benveniste \& Paul Spindt, How Investment Bankers Determine the Offer Price and Allocations of New Securities, 24 J. Fin. Econ. 343 (1989); see also Wilhelm, supra note 58. 
getting soft dollar kickbacks in return. ${ }^{91}$ The IPO scandals in the aftermath of the tech stock bubble a little more than a decade ago exposed some of these temptations. ${ }^{92}$ But won't issuers-who are hardly unsophisticatedlearn to resist this exploitation? Maybe not, for a variety of reasons. Perhaps there is collusive behavior by the securities industry that makes issuer resistance difficult, or maybe underpricing is palatable to the issuer because it provides some insurance against the draconian liability that the Securities Act generates. The most common explanation, however, is that the issuer's insiders see personal profit opportunity in the underpricing because the "pop" may enable greater profits when they sell their own shares later on, when lock-up agreements expire. ${ }^{93}$

These are not Section 5 problems, however, at least not directly. If book-building is about a delicate negotiation between the underwriters and institutional investors leading to systematic underpricing of IPOs, we need not worry about these investors. While there will be retail investors as well in the initial round of sales, the fixed-price offering means they will get the same mark-down as the institutions. Thus, in the absence of retail-only IPOs, we might reasonably wonder why we need Section 5's sales restrictions at all. Institutional investors presumably do not need to be told to wait and read the prospectus before deciding to invest if they find that information necessary or valuable (which certainly justifies the JOBS Act's new Section 5(d)).

We may have to be somewhat cautious here, however. One of the insights of the economics literature is that underwriters and preferred customers (the major institutions) are repeat players whose interactions extend among many offerings. An institution might make a generous bid in one offering with the expectation that it is helping out the underwriters now, expecting compensation in other ways or other deals. So, we cannot be entirely confident that the institutional pricing mechanism assures fairness in any given deal. Moreover, institutions can exit fairly quickly in the aftermarket, relying on the underpricing for short-term protection. ${ }^{94}$ While

91 See Hsuan-Chi Chen \& Jay Ritter, The Seven Percent Solution, 55 J. Fin. 285 (2000); see also William K. Sjostrom, The Untold Story of Underwriting Compensation Regulation, 44 U.C. Davis L. Rev. 625 (2010).

${ }^{92}$ See sources in note $[\mathrm{X}]$ supra.

${ }_{93}$ E.g., Daniel Bradley et al., The Quiet Period Goes Out with a Bang, 58 J. Fin. 1 (2003).

${ }^{94}$ See Thomas Chemmanur et al., The Role of Institutional Investors in Initial Public Offerings, 23 Rev. Fin. Stud. 4496 (2010) (institutional sell approximately 70\% of their 
underwriters naturally want to discourage too much early flipping, this is all negotiable.

In any event, the major Section 5 problems are less likely to arise from book-building solicitations than from the impact of the offering on secondary market trading. ${ }^{95}$ Under-pricing is a function of the difference between the fixed offering price and the likely after-market price; the higher the latter, the more valuable the allocations. For that reason alone, underwriters will try to stimulate investor demand beyond the initial round of buyers. Moreover, a threat to include more retail investors in a particularly hot offering might encourage the institutions to be more generous in their book-building bids. To the extent that issuer insiders are anxious to take advantage of lock-up expirations occurring a while after the effective date, they, too, will reward underwriters who work to stimulate secondary market demand. Recent empirical evidence supports the idea that such stimulation is part of the underwriters' job, for which they are well compensated. $^{96}$ The evolution of social media (Twitter, Facebook, Linkedin, etc.) has expanded the mechanisms for doing this.

Assessing this is difficult, however, because offering participants are hardly the sole cause of positive investor sentiment in anticipation of an IPO. The financial media covets emerging growth company stories, especially among issuers with visible brand names, and can hype without prompting. Investor enthusiasm can spread virus-like by word of mouth or the electronic equivalent, amply visible through simple tools like counting Google searches for pre-IPO issuers. ${ }^{97}$ Identifying or measuring how much offering participants induce enthusiasm, then, is impossible in a noisy financial marketplace. But the studies noted above make clear enough that efforts in this direction are expected, with compensation that is presumably not for nothing.

allocations in the first year, and are rewarded for holding by future allocations); Reena Aggarwal, Allocation of Initial Public Offerings and Flipping Activity, 68 J. Fin. Econ. 111 (2003).

95 Id.; see also Daniel Bradley et al., The IPO Quiet Period Revisited, 2 J. Inv. Mgt. (2004); Pritchard, supra note 89, at 1014-15.

${ }^{96}$ See Douglas O. Cook, et al., On the Marketing of IPOs, 82 J. Fin. Econ. 35 (2006); see also Francois Derrien, IPO Pricing in "Hot" Market Conditions: Who Leaves Money on the Table?, 60 J. Fin. 487 (2005); Alexander Ljungqvist et al., Hot Markets, Investor Sentiment and IPO Pricing, 79 J. Bus. 1667 (2006).

${ }_{97}$ See Zhi Da et al., In Search of Attention, 66 J. Fin. 1461 (2011). 
A circumstantial case for these IPO marketing practices follows from a well-known anomaly: that even though underpricing is clear, in the long run IPOs underperform. ${ }^{98}$ That is to say, the predictable profit opportunities may disappear fairly quickly, and investors who buy (especially in the aftermarket) and hold IPOs over a longer time horizon do not do that well. There are many explanations given for this, including timing (issuers make their IPOs when at the top of their game ${ }^{99}$ ), financial reporting (issuers take advantage of accounting discretion to maximize their current profitability and/or growth at the expense of future reporting) and the aggressive marketing of the IPO itself. The steady increase in the supply of stock for sale and borrowing, which facilitates short-selling, also puts downward pressure on the price that was missing in the early days of trading. Arguably, sophisticated investors in IPOs may know to get out early except when they have confidence they have found one of the winners.

We have to be careful not to overstate all this. There is evidence, for example, that underperforming IPOs are heavily concentrated at the low reputational end of the spectrum, where the institutional presence is weakest. ${ }^{100}$ Nor is it clear that aggressive media coverage necessarily correlates with long-run underperformance. ${ }^{101}$ Thus we cannot simply assume the presence of rampant opportunism directed at the retail aftermarket. But we cannot rule it out either, particularly given the cyclical variations in capital raising patterns over time.

\section{B. Economics Confronts Law}

\footnotetext{
${ }^{98}$ See Jay Ritter, The Long Run Underperformance of Initial Public Offerings, 46 J. Fin. 3 (1991).

99 See Tim Loughrin \& Jay Ritter, The New Issues Puzzle, 50 J. Fin. 23 (1995); see also sources cited in note $[\mathrm{X}]$ supra.

100 See Alon Brav \& Paul Gompers, Myth or Reality?: The Long Run Underperformance of Initial Public Offerings, 52 J. Fin. 1791 (1997); Laura Field \& Michelle Lowry, Institutional Versus Individual Investment in IPOs: The Importance of Firm Fundamentals, 65 J. Fin. \& Quant. Analysis 489 (2009).

101 See LaURA LiU et AL., The LONG-Run Role OF the Media: EvidenCE from Initial PUBLIC OFFERINGS (Feb. 2012).
} 
The devolution of Section 5 has plainly made it easier to "pump" IPO stocks. The 2005 reforms, as we have seen, allows even "hyping" publicity up until 30 days before the filing of the registration statement so long as it does not reference the offering (even though the offering can be announced separately), and free writing prospectuses during the waiting period can generate mass media publicity with nothing more than a filing requirement, as well as more targeted communications via e-mail and the internet. Backdoor hyping mechanisms like product advertising are arguably made easier by Rule 169 even within the 30 day window, continuing through the waiting period. ${ }^{102}$ The JOBS Act redefinition of "research" within the statutory definition of offer opens up even more potential for conditioning the market prior to the effective date; the Act's more explicit instruction that brokers involved in the underwriting can initiate research coverage of the EGC immediately, with predictable "buy" recommendations, is by all accounts a freedom to pump.

None of this will come as any surprise to those familiar with the 2005 reforms or the JOBS Act, however. The drafters of both did not deny that more aggressive publicity would result; rather, they argue that serious abuses are unlikely. One reason has to do with institutional investors as protectors of the retail given that offerings are fixed price. Another has to do with the modern information environment, which gives potential investors access to information about issuers from a wealth of sources, presumably making public offering fraud harder to perpetrate. While there is no doubt something to the idea that hiding the truth is more difficult today than in the past, contemporary frauds like Enron, Worldcom and many others show that issuer opacity remains problematic. ${ }^{103}$ Indeed, modern technology can amplify fads and fashions as much as it can expose the truth. Especially without short-selling opportunities to profit from at the time of the IPO, the few skeptical voices interested in popping a bubble of excitement are likely to be silenced by the din of enthusiasm from those anxious for an offering to succeed. We are thus disinclined to put too much faith in this argument.

\footnotetext{
102 Rule 169 does restrict advertising and other "factual" communications to that which is consistent with the issuer's normal practices. For evidence on the use of advertising to promote public offerings, see Thomas Chemmanur \& An Yan, Product Market Advertising and New Equity Issues, 92 J. Fin. Econ. 40 (2009).

${ }^{103}$ For an estimate, see AleXANDER DyCK ET AL., HOW PERVASIVE IS CORPORATE FraUd? (Feb. 2013), available at www.ssrn.com/abstract $=2222608$ (inferring that as many as $14.5 \%$ of publicly-traded issuers are engaged in fraud at a given time).
} 


\section{Liability Rules}

The other arguments that fear of opportunism is overblown are largely liability-based. One is that no reform has touched the centerpiece of the Securities Act: the registration statement with its extensive disclosures about the issuer and the offering, which is publicly available by the time serious marketing of the IPO commences and which - as of the effective date-must be true and complete lest extraordinarily strict liability ensue. ${ }^{104}$ This by itself should be a counterweight to any false or misleading hype, which is the only hype worth worrying about. We come back to this in Part III.

The other is that there is a set of civil liability and conduct rules that can be relied upon to deter overreaching in the marketing of the IPO. With respect to the expansion of research carve-outs in the JOBS Act, for example, the drafters point to SEC and FINRA rules that are designed to promote analyst independence from pressure from others in the investment bank, most of which were untouched in the reforms. There are also both substantive and procedural limits on solicitation efforts-for example, "know your security" norms, which require brokers to be familiar with issuer-related information before making any recommendations to customers, ${ }^{105}$ and communication rules that require supervisory approval of brokers' written outreach efforts, which now includes social media. ${ }^{106}$ All this relates to a point we have made elsewhere: the Securities Act was enacted a few years before the advent of substantive broker-dealer regulation, so that maybe the subsequent emergence of those direct controls on the selling effort can substitute for the overbroad prophylactics in the statute. ${ }^{107}$

There is much to be said for this, and we could imagine a technology-enhanced system of real-time surveillance of the sales and marketing practices associated with IPOs and other sensitive transactions

\footnotetext{
104 Section 11 of the Securities Act; see CoX ET AL., supra note 2, at 485-515.

105 Id. at 1033-38.

106 FINRA Rule 2210; Regulatory Notice 11-39.

107 See Thompson \& Langevoort, supra note 1.
} 
that would indeed justify relaxation of the statutory rules. Whether we are at such a point is open to question, however. Our sense is that the pressure to market aggressively will find expression in ways that are difficult to detect or prove as violations. For example, analysts doing research do not need to have compensation set based on their contributions to the banking side to realize that their career prospects are better if they are in synch with their employers' deal flow. And investment banks can hire optimists for this kind of work if there are any doubts, for whom genuine enthusiasm for favored stocks comes easily. We can say the same about brokers doing other kinds of hard-sell marketing.

But if these softer rules are not powerful enough, maybe other civil liability rules are. The SEC was clear that their philosophy was deregulate communications that were not necessarily troublesome and then use ex post liability to address the abuses when they are uncovered. These include SEC and FINRA enforcement actions, for which there is ample authority. Section 17(a) of the Securities Act, for example, creates liability for misrepresentations or omissions in the offer or sale of a security, without the need to prove intentional misconduct. ${ }^{108}$ Here again, however, the question is whether enforcement resources and detection mechanisms are up to the task.

Private lawsuits by IPO investors add a larger dimension to the policing of abusive marketing practices, to which SOR assigns an important role. Putting aside for a moment situations where the registration statement itself is false or misleading as of the effective date, two private rights of action can be invoked: Rule 10b-5, and Section 12(a)(2).

Rule 10b-5 - the general antifraud provision under the federal securities laws - is not particularly helpful, however, outside the most egregious of IPO cases. It requires plaintiffs to plead and prove scienter, ${ }^{109}$ which is not always easy when offering participants seem caught up in deal euphoria. It also has a challenging "loss causation" standard, whereby plaintiffs have to show that their stock price losses were the product of the revelation of the truth about what had been misrepresented, rather than other economic factors. High-visibility cases challenging biased investment bank research in IPOs have collapsed simply because of this difficulty. ${ }^{110}$ But

108 See COX ET AL., supra note 2, at 547-50.

109 That is, proof of intentional or reckless fraud. See id. at 707-11.

110 See Lentell v. Merrill Lynch, 396 F.3d 161 (2d Cir. 2005). 
the most powerful impediment to 10b-5 litigation here is procedural: private enforcement by investors has to take the form of a class action to be effective, and courts have not been willing to afford plaintiffs the presumption of reliance in the IPO context that they do in other openmarket fraud lawsuits because the IPO and immediate aftermarket trading does not occur in an sufficiently "efficient" market. ${ }^{111}$ Without that presumption, the class action is simply not certified.

This leaves Section 12(a)(2), which the SEC promoted in the 2005 reforms as the primary response to fear of abusive marketing. ${ }^{112}$ This statutory provision allows buyers of securities to sue their sellers for rescissory damages if securities were sold by means of a false or misleading "prospectus or oral communication," subject to a reasonable care defense. ${ }^{113}$ The statutory definition of prospectus refers to any written offering material, upon which the Supreme Court put a gloss in the Gustafson decision by limiting this category to offering materials used in a public offering. ${ }^{114}$ The 2005 reforms makes clear that in the opinion of the SEC, marketing materials used in a registered public offering, including free writing prospectuses, satisfy this definition. ${ }^{115}$ The SEC also adopted a number of rules to bolster plaintiffs' ability to sue.

Of these, the most potent relates to the definition of seller, who is the only permissible defendant in a 12(a)(2) suit. The case law had defined seller as including only those who passed title to the security to the buyer (i.e., one's immediate seller) and those who solicit on behalf of the seller. This creates problems in the context of the firm commitment underwriting, because the securities would move from the issuer to the underwriters and then perhaps another step or two before coming to rest in the hands of the investor who claims abuse. The SEC took the view that underwriters and other offering participants had enough of a seller role to fall within the scope of the term as understood by the courts-which itself is a little bit of a stretch. But what about the issuer, which stands at least a step away from

\footnotetext{
111 In re IPO Sec. Litig., 471 F.3d 24 (2d Cir. 2006).

112 In his criticism of the SEC's approach to free writing prospectuses, Thel notes that the adopting release refers to 12(a)(2) more than seventy times. See Steve Thel, Free Writing, 33 J. Corp. L. 941, 962 n. 99 (2008).

113 See COX ET AL., supra note 2, at 528-46.

114 Gustafson v. Alloyd Co., 513 U.S. 561 (1995).

115 See Thel, supra note 112, criticizing the SEC's approach to 12(a)(2) liability for free writing prospectuses that are not widely distributed.
} 
the ultimate purchaser? The case law here was mixed, and so the SEC used its definitional rulemaking authority in Rule 159A simply to declare the issuer a seller for purposes of 12(a)(2) with respect to marketing material for which it bears responsibility. ${ }^{116}$ With this, the Commission said, victims of abusive marketing were protected from any unfortunate consequences of Section 5's partial disappearance. This would include misrepresentations or omissions in the preliminary prospectus, free writing prospectuses, or related oral or written solicitations.

This is undermined, however, by at least four key weaknesses. As to the widened definition of "seller" in Rule 159A, which is crucial to effective policing, a surprisingly large number of courts have been inclined to stick with the older case law, often not even mentioning the rule-based change. A few have held that the SEC lacks the authority to change the definition. ${ }^{117}$ This may reflect a tendency observable elsewhere in securities litigation, wherein courts are doubtful that the SEC should control the sensitive subject of private litigation rights.

Beyond this, there is substantial doubt as to whether Section 12(a)(2) applies to secondary trading as opposed to sales by underwriters and dealers as part of the IPO itself. The "majority opinion" seems to be not, ${ }^{118}$ which means that aftermarket purchasers have no recourse even if Rule 159A stands.

The next weakness takes us back to the issue of reliance and the ease of class certification that has been the subject of so much litigation under Rule 10b-5. It is generally said that Section 12(a)(2) has no reliance requirement. $^{119}$ But that construal dates back to the original idea that prospectuses were extremely limited prior to the effective date, so that

11617 CFR §230.159A. The Supreme Court has construed the term "seller” in Section 12(a) to include only the person who transfers title to the security to the purchaser, and any other person who, for pecuniary benefit, solicits the transaction. Pinter v. Dahl, 486 U.S. 622 (1988).

117 See In re Kosmos Energy Sec. Litig., 2013 WL 3196437 (N.D. Tex. 2013); Countrywide Fin. Corp. MBS Sec. Litig., 2013 WL 1189311 (C.D. Cal. 2013); Mass. Mut. Life Ins. Co. v. Residential Funding Co., 843 F. Supp.2d 191 (D. Mass. 2012). For a contrary view, accepting the rule as valid, see Capital Ventures Int'l v. J.P. Morgan Mortgage Acquisition Corp., 2013 U.S. Dist. LEXIS 19227 (D. Mass. 2013).

118 See Johnson v. Sequans Comm. S.A., 2013 WL 214279 (S.D.N.Y. 2013); Rogers v. Sterling Foster \& Co., 222 F. Supp. 2d 216 (S.D.N.Y. 2002).

119 See LOSS ET AL, supra. 
statutorily-authorized free writing was only really a post-effective possibility (where it received an explicit exemption from the definition of prospectus ). ${ }^{120}$ Thus there really was very little role for 12(a)(2) liability at all, except with respect to offerings of exempt securities-where the offering document was the functional equivalent of the statutory prospectus. $^{121}$ Thus it made sense for there to be no reliance requirement (just as there is no reliance requirement under Section 11 for false registration statements) because the importance of that document could be presumed. The 2005 reforms, however, radically revised this, inviting all kinds of communications of varying degrees of visibility and import. As a matter of common sense, 12(a)(2) will not work without some insistence that a buyer trace his or her purchase back to the defective prospectus, and the language in the provision that recovery is appropriate when the securities were sold "by means of" the false prospectus invites precisely this inquiry. $^{122}$ If so, there could be at least a backdoor reliance requirement. And if so, it is highly likely that class certification-the key to effective enforcement in private securities litigation-will fail. If claimants have differing reliance explanations, courts may well insist on individualized claims, which probably means few or no claims. To date, class certification is still commonplace in 12(a)(2) cases, but largely in contexts where it is a tag-a-long to Rule 10b-5 or Section 11 claims. How much weight it can bear on its own is questionable.

The final weakness takes us back to the definition of prospectus. We will assume that the SEC is right that the definition of prospectus is broad enough to include free writing generally. But there are notable exceptions. The Securities Act explicitly carved out from the definition of prospectus any free writing after the effective date that is accompanied or preceded by a statutory prospectus. ${ }^{123}$ More dramatic is the effect of the JOBS Act on EGCs. Any communication by an underwriter or dealer that falls in the seemingly broad definition of "research" found in Section

120 The preliminary prospectus would be an exception, of course, but Section 11 dominates liability here so that where the falsity continued on through the final prospectus, buyers would have no reason to resort to Section 12(a)(2).

121 See Sanders v. John Nuveen \& Co., 619 F.2d 1222 ( $7^{\text {th }}$ Cir. 1980), cert. denied, 450 U.S. 1005 (1981) (public offering of commercial paper).

122 Some courts have suggested the need for a showing that the prospectus played "some role" in the purchase, which could be a very individualized inquiry. See Alton Box Co. v. Goldman Sachs \& Co., 560 F.2d 916, 924 (8 ${ }^{\text {th }}$ Cir. 1977) (“some causal relationship’).

123 See Thel, supra note 112, discussing this history. 
2(a)(3) is excluded from being an offer or a prospectus. Read literally, as we have seen, that would put most if not all forms of conditioning the market by broker-dealers entirely out of the reach of 12(a)(2).

All this suggests that 12(a)(2) may not be a very reliable policing mechanism at all, which is troubling given how much stress the SEC put on it in 2005. We suspect that only the SEC and FINRA can realistically address abuses in conditioning the market, with the doubts about resources and inclination that are inevitable when dealing with public (or quasipublic) enforcement authority. To this point, then, there is no compelling response to the concern that the slow death of Section 5 puts IPO investors more at risk, at least in the secondary market.

\section{The Statutory Prospectus and the Filtration Process}

The great anomaly of Section 5 has been well-known almost from its inception: it seemingly works hard to make the disclosure document (the part of the registration statement at the effective date that constitutes the final statutory prospectus) an effective truth-telling tool, yet rarely requires delivery of it to the investor until after the purchase is complete. ${ }^{124}$ One might justify the death of Section 5 on this basis alone. But for just as long, the reality has been that the work of disclosure is done not by the final prospectus but by the preliminary prospectus - a filed draft of the disclosure in final-enough form, which sets an offering price range and typically has already been revised in response to initial SEC staff comments. ${ }^{125}$ In administering Section 5, the SEC has long insisted on distribution of the preliminary prospectus to offering participants and investors who request one; in an IPO, moreover, Rule 15c2-8 requires that each purchaser expected to buy receive a preliminary prospectus at least 48 hours before the sale. Attachment or linkage of the preliminary prospectus is a condition to the use of most free writing during the waiting period. And if the SEC staff comes to think that what is in the preliminary prospectus needs

124 Louis Loss called it a "momento" of the sale. Thel, supra note 112, says that the exception for free writing in the definition of prospectus was designed to compensate for this by giving issuers and underwriters an incentive to distribute the final prospectus earlier.

${ }^{125}$ See CoX ET AL., supra note 2, at 172-73. 
significant change, it will delay effectiveness long enough to permit recirculation or updating. ${ }^{126}$

This is the real function of the Securities Act, largely untouched by the 2005 reforms or the JOBS Act. The latter does permit confidential filings so that the early round of disclosure negotiations with the SEC can be kept private, but road shows and other significant marketing steps cannot take place until after the "improved" preliminary prospectus has been filed publicly. By all accounts, misrepresentations in this document trigger Section 12(a)(2) liability for the seller, albeit subject to the litigation caveats stressed earlier.

In many ways, the demise of Section 5 that we have traced is most readily defended this way. What is important is high quality disclosure throughout the marketing period, so that overbroad marketing restrictions are unnecessary and costly. Those who doubt that many investors actually make much use of the disclosure itself generally justify this core set of obligations by reference to "filtration": that what is important during the marketing of an IPO is that the professionals be informed of the truth about the issuer, so that their recommendations and related activity will reflect reality rather than hype. ${ }^{127}$

We don't doubt that the importance of filtration, even via professionals with conflicts of interest (which is a larger category as a result of the JOBS Act "research" amendments). Surely negative or qualified facts about a company's past limit salespeople's ability to promote aggressively. The problem with the statutory prospectus, preliminary or otherwise, is that it is almost entirely historical (backwards-looking) in what it reveals, whereas the story that drives the marketing of an IPO is about the issuer's future. The typical IPO issuer has shown promise; the economics literature and common sense suggest that public offerings are timed to take advantage of a sense of momentum at a high point in its perceived valuation. What reasonable investors should want to know about is the sustainability of this promise and momentum.

Litigation under the Securities Act often deals with issuers that make public offerings not long before hitting a rough patch-product

126 See John Jenkins, Recirculation of the Preliminary Prospectus: Statutory Basis and Analytical Techniques for Resolving Recirculation Issues, 55 Bus. Law. 135 (1999).

127 See Cox, supra, note 12 at 12-17. 
defects or sales slumps - that sends the stock price downward. Plaintiffs may offer evidence that, internally, management was aware of warning signs, perhaps even leading them to lower their private estimates of revenues or earnings at least in the short term. They will claim that the statutory prospectus was false and misleading for failing to reveal the looming dangers.

Predictably, defendants will respond by stressing that the Securities Act does not require issuers to divulge forward-looking information even if it is material. ${ }^{128}$ The obligation, they say, is simply to obey the SEC's lineitem requirements and include such additional information as is necessary to make these disclosures not misleading. For better or worse, they are right. As a result, plaintiffs in these lawsuits are forced to argue that what was said about past results was misleading for failure to mention the danger signs, which is not easy unless the issuer voluntarily put the subject of continuing or future performance in play. By and large, courts say that truthfully revealing historical facts does not imply that the future will not be different.

To be sure, there are a couple of line-item requirements that do turn to the future, on which plaintiffs also seize. There is a duty to disclose major risk factors, but this requires qualitative revelation of types of risk, not quantitative disclosure about the likelihood or impact of those risks. IPO lawyers are usually good about including extensive risk disclosures, without specifics. There is also the Management Discussion and Analysis (MD\&A) portion of the statutory prospectus, which requires disclosure of "known trends and uncertainties" that would lead an investor to doubt that past financial performance indicates a comparable future. ${ }^{129}$

Sometimes these arguments work, particularly where what the company is facing evidences an "extreme departure" from its past

\footnotetext{
128 See COX ET AL., supra note 2, at 643-45, 662-63. For a discussion of the somewhat confusing law surrounding the duty to disclose, see Donald C. Langevoort \& G. Mitu Gulati, The Muddled Duty to Disclose Under Rule 10b-5, 57 Vand. L. Rev. 1639 (2004). The highly publicized litigation involving Facebook's IPO contains all of these issues. See In re Facebook Inc. IPO Sec. \& Deriv. Litig., 2013 WL 525158 (S.D.N.Y. 2013)(derivative suit dismissal). For defendants' presentation of these arguments-heavily contested by plaintiffs-see Memorandum in Support of Defendants' Motion to Dismiss the Consolidated Class Action Complaint, 2013 WL 1874694, May 1, 2013.

${ }^{129}$ Item 303 of Reg. S-K, 17 CFR §220.303; see COX ET AL., supra note 2, at 606-11.
} 
success. ${ }^{130}$ But more often, it seems, courts revert to the basic principle that forward-looking information is not the subject of mandatory disclosure, particularly when they take the form of projections or estimates. ${ }^{131}$ The issuer has to be honest about its past but need not reveal all doubts about its future, at least so long as it chooses to remain discretely silent on such matters rather than saying something affirmatively misleading.

In sum, what the statutory prospectus reveals to whoever chooses to read it is not necessarily the whole story about the issuer. The SEC has deliberately restricted the duty to speak to the future, and discourages IPO issuers from doing so publicly, even if they want to. ${ }^{132}$ For this reason alone, we have to question exactly how much "filtration" value the preliminary prospectus has in restraining marketing and hype.

In the course of book-building, however, sophisticated institutional investors demand access to what the issuer knows about its future. This is the function of non-public road shows and related communications during the waiting period. It is commonplace for issuers to reveal forward-looking information to the underwriters and their research analysts, from which assessments of the future can be made. These, in turn, are shared with key potential buyers, with an expectation of privacy. This discriminatory treatment-selective disclosure-is acceptable practice as a means of encouraging institutions to be forthcoming with their bids, which as we have seen is key to successful book-building. Recognizing this, the SEC has explicitly excluded public offerings from the scope of Regulation FD, ${ }^{133}$ which otherwise limits selective disclosure to market professionals and large investors.

All this underscores our basic point. For better or worse, the publicly-available disclosure found in a preliminary prospectus will often be distinctly less than everything a reasonable investor would want to know, or even everything that institutional investors are actually getting from the

\footnotetext{
${ }^{130}$ See Shaw v. Digital Equip. Co., 82 F.3d 1194 (1 $1^{\text {st }}$ Cir. 1996); G. Mitu Gulati, When Corporate Managers Fear that a Good Thing is Coming to an End, 46 UCLA L. Rev. 675 (1999).

${ }^{131}$ E.g., In re Lyondell Petrochemical Sec. Litig., 984 F.2d 1050 ( $9^{\text {th }}$ Cir. 1996).

132 Congress joined in here as well, creating a safe harbor for forward looking information in the Private Securities Litigation Reform Act but exempting IPOs from its protection. See Securities Act §27A(b)(2)(D), 15 USC §77aa-1(b)(2)(D).

13317 C.F.R. §243.100(b)(2)(iii). This was expressly reaffirmed in the 2005 reforms. See 70 Fed. Reg. at 44760.
} 
issuer and the underwriters. If this inside information is thoroughly positive, this may be unproblematic - the institutions will bid up the fixed offering price, and indeed there may also be aftermarket buyers beyond the amount of their allocations. In this regard the SEC's long-standing willingness (including in Reg FD) to accept this departure from full disclosure for every investor reflects the value of encouraging the private information flow from purchasers to the issuer and underwriter that bookbuilding has long embodied.

If the inside information is negative, however, things get more complicated. At some level of bad news, of course, the institutions will lose interest entirely — at that point, however, the underwriters would likely have backed out as well. But as noted earlier, if the negative information is more ambiguous and the likely demand from the yet-unaware retail public is strong enough, the better strategy might be to buy but then sell fairly quickly, especially if the underwriters will tolerate aggressive reselling and/or settle up with preferential treatment in more attractive future IPOs. If so, the gap between public and private disclosure, and the use of bookbuilding theory to justify the difference, remain troublesome. We believe that the Commission should do more here, perhaps in the nature of a special MD\&A requirement for IPOs that sheds more light on how well the expectations that have been created in the marketplace mesh with the current realities facing management internally.

\section{CONCLUSION}

One of Section 5's two original functions, its severe restriction on selling communications outside of the required disclosure, has practically disappeared. In part this reflects the SEC's belief, which has grown over time, that a combination of filtered disclosure and strong liability will take care of the problem. The extraordinary expansion in information available through new electronic communication capabilities no doubt has also contributed. One of our contributions here is to show the concern for facilitating the flow of information from purchasers to issuers and underwriters, as illustrated in book building, provides another important explanation. 
Our survey of the demise of Section 5's communication rules should be cautionary, however. Even in a world in which the initial fixed price buyers are heavily institutional and presumably able to fend for themselves (and do indeed extract more disclosure than the law requires), the ability to condition the market is less restrained than it used to be. Aftermarket buyers, at least, would appear to be more at risk. The justifications for backing off the old prophylactics—especially the supposed liability threats - do not bear as much weight as their proponents suggest.

That doesn't necessarily mean, however, that the demise is bad public policy. Some level of reform was both necessary and inevitable. ${ }^{134}$ Perhaps legal costs go down in a more permissive environment, though anyone who goes through the 2005 reforms mind-numbing complexity on when to file a free writing prospectus pursuant to Rule 433 would be skeptical of this. Another possibility is that the anachronistic communication rules from 1954 never worked that well for investors anyway, so that there was little actually lost. ${ }^{135}$ We are not aware of empirical study of the 2005 reforms that would help us tell, and the JOBS Act is much too recent to make any judgments.

Our strong suspicion, however, is that this turns out to be a story about the trade-offs between capital formation and investor protection. The JOBS Act comes close to acknowledging that motivation. There was little effort in the legislative history to say that investors would be better off because of these changes - rather, the IPO changes were designed to make registered public offerings more appealing to entrepreneurs deciding whether to make one or not. If more jobs come about as a result, we can hardly say for sure that a moderate erosion of investor protection wasn't worth it. Like others, however, we will wait with some skepticism to see precisely what comes.

For skeptics about IPOs, this story may simply bolster the need for sweeping changes. The claim that both capital formation and investor protection would be improved by IPO auctions rather than a continuation of

\footnotetext{
${ }^{134}$ See Cox, supra note 12, at 24-25.

135 Conversely, it is also possible that the reforms have not really be taken advantage of, so that marketing practices stay much like they were even in a more liberalized setting. Those who believe that the First Amendment demands a more permissive approach to commercial speech by issuers and underwriters could justify the changes by that reason alone. See note 8 supra.
} 
book-building has been made in both the economics and legal literature. ${ }^{136}$ Or perhaps, as Adam Pritchard suggests, we should just declare IPOs offlimits to retail investors, insisting on a period of seasoning for new issuers in the private securities markets before they graduate to the public ones. ${ }^{137}$

The merits of these proposals are beyond this article. IPOs are enough part of the popular culture of finance to survive academic or political doubts about their fairness and efficacy. Their lottery-ticket appeal is hard to deny. Retail investors' tendency to become infatuated with an issuer and support its aftermarket long enough for financial institutions to make their money is precisely the point.

Even though we are concerned, we do not want to be alarmist about all this. The bulk of the Securities Act as it applies to public offerings remains, regardless of the demise of the communications bar in Section 5. The 2005 reforms and the JOBS Act made moderate reforms, not radical ones. The SEC is still in control of the registration process, and severe civil liability still attaches to falsity in the registration statement upon its effectiveness. But once, there was a political instinct to do more to restrain the selling process. Why this is less so today is worth more attention than both legal scholars and investors are giving it.

136 See, e.g., Hurt, supra note 13; but see Peter Oh, The Dutch Auction Myth, 42 Wake Forest L. Rev. 853 (2007).

137 See Pritchard, supra note 89. 